\title{
Japan to double university project grants
}

Tokyo. Japan's Ministry of Education, Science, Sports and Culture (Monbusho) is seeking to double the budget next year of a programme that will support university research with hundreds of five-year project grants, which will each be worth an average of about US\$1 million a year. The move is part of a broad effort by science-related ministries to boost government spending on science and technology by 50 per cent over the next five years.

The programme, 'Research for the Future', was introduced this fiscal year by the Japan Society for Promotion of Science (JSPS), a semigovernmental organization run by the ministry and well-known internationally for its postdoctoral fellowships and exchange schemes for foreign scientists wishing to do research in Japan.

Less well known is its role in funding domestic postdoctoral fellowships for Japanese university researchers. In line with both responsibilities, the new programme includes support for several hundred postdoctoral 'research assistants', and will also involve participation by foreign scientists.

JSPS won an unusually large initial budget of $¥ 11$ billion (US $\$ 100$ million) for the programme in the current fiscal year, which began on 1 April, and, earlier this summer, review committees selected 117 projects in 17 research fields that will each receive on average about $¥ 100$ million a year for the next five years.

Next year, in an unusual move, the ministry hopes to double this budget to $¥ 22$ billion, as revealed in its budget request to the Ministry of Finance, submitted at the end of last month (see table, right). If accepted, as seems likely in the present political climate, JSPS will have more than trebled its total budget, from $¥ 12$. 4 billion in 1995 to $¥ 41.1$ billion in 1997 , making it a much more powerful player in Japan's university research.

The large increase is possible because the programme is classified as 'capital invest-

\begin{tabular}{|c|c|c|}
\hline \multicolumn{3}{|c|}{$\begin{array}{l}\text { Highlights of } 1997 \text { science budget request for Japan's } \\
\text { Ministry of Education, Science, Sports and Culture }\end{array}$} \\
\hline & $+¥$ billion & $\%$ change \\
\hline Grants in aid of research & 114.1 & +12.1 \\
\hline $\begin{array}{l}\text { Japan society for promotion of science } \\
\text { (Research for the future) }\end{array}$ & $\begin{array}{l}41.1 \\
(22.0 *)\end{array}$ & $\begin{array}{c}+56.1 \\
(+100.0)\end{array}$ \\
\hline Joint research with industry & 48.3 & +38.4 \\
\hline Academic information networks & 36.5 & +10.2 \\
\hline
\end{tabular}
ment', which is usually funded by national bonds rather than taxes. As such, it is free from the ceilings normally imposed on science budgets by the Ministry of Finance. This is the first time that capital investment funding, normally reserved for public works projects, has been applied to university research grants and the payment of salaries

\section{Accelerator complex gains momentum}

Tokyo. Monbusho's budget proposal for next year (see above) includes a relatively small request of $¥ 167$ million (US\$1.5 million) to begin the establishment of a huge new complex for research using high-energy accelerators in Tsukuba science city, northeast of Tokyo. The complex will employ about 800 people, and will draw together researchers from the National Laboratory for High Energy Physics (KEK) in Tsukuba with Tokyo University's Institute for Nuclear Study (INS) and its Meson Science Laboratory.

Two new institutes will be formed. One will carry out research into nuclear and fundamental particle physics, and another will be for the study of the structure and function of materials. These will be built around an accelerator research facility, including the B-factory now under construction by KEK and a $50-\mathrm{GeV}$ proton synchrotron proposed by INS (see Nature 376, 454; 1995).

The formation of the research complex comes at a time when KEK has been in need of a new purpose, following the shutdown of the TRISTAN electronpositron collider. At the same time, INS, which is based in the northwest suburbs of Tokyo, also needs rejuvenation and new facilities. One aim is to broaden the research of the old organizations to encompass application of accelerators to materials science and structural biology.

INS and the meson laboratory will cease to be part of Tokyo University, and the institutes and complex will take on the status of national institutes for joint university use, similar to that of the complex of three such institutes for basic biology, molecular science and physiology in Okazaki near Nagoya. As such, the former Tokyo University organizations can look forward to better funding. But they may find it harder to recruit high-quality graduate students because of their loss of a direct link to Japan's leading national university.

The proposal to build a $50-\mathrm{GeV}$ proton synchrotron, which is expected to cost about $¥ 75$ billion (US $\$ 680$ million), has yet to win the go-ahead from the government. But observers say that the project is almost certain to get approval once establishment of the complex begins. Hirotaka Sugawara is widely tipped to become director general of the whole complex, while Sakue Yamada, who is currently director of INS, is expected to head the institute for nuclear and fundamental particle physics.

D. S. for young researchers, and indicates the seriousness of the government's commitment to a significant increase in funding for science.

The laws governing JSPS had to be revised to allow capital-investment funding. This legislation was passed at the end of May, and a programme committee headed by Hiroyuki Yoshikawa, president of Tokyo University, subsequently set up 17 subcommittees to select projects for universities and Monbusho-affiliated institutes throughout Japan.

These programmes include projects in new materials, molecular-scale surface dynamics, next-generation process technology, computer science, synthesis science, micromechatronics, biotechnology, human genome research, cell signalling, bioinformatics, brain research, structural biology, life science, developmental biology and medical engineering. Other items in Monbusho's budget request also receive large increases, although none as much as the JSPS. Competitive 'grants in aid of research' continue their rapid growth, with a proposed 12.1 per cent increase for next year to $¥ 114.1$ billion. This combined with the new JSPS scheme will provide substantial new funds for university research.

The budget for universities to carry out joint or commissioned research with industry also receives a substantial boost of 38.3 per cent. But donations from industry are expected to remain flat because of the lingering effects of the recession.

Computer networks and new electronic information systems for libraries continue to gain large increases in their budgets, with plans to upgrade the maximum capacity of the national network linking universities to 150 megabits per second in key sections. Budgets for large facilities under construction, such as the infrared telescope in Hawaii, the B-factory in Tsukuba science city, and the helical fusion device in Gifu Prefecture also get substantial increases.

As part of a commitment to double the number of postdoctoral fellows working in Japan to 10,000 by the end of the decade, the JSPS also requests a large expansion in its fellowship programmes. This includes an increase from 420 to 750 in postdoctoral fellowships for foreign scientists to come to Japan (see Nature 383, 195; 1996). 